\title{
OBITUARY
}

\section{DONNY GEORGE YOUKHANNA, B.A., M.A., Ph.D. $(1950-2011)$}

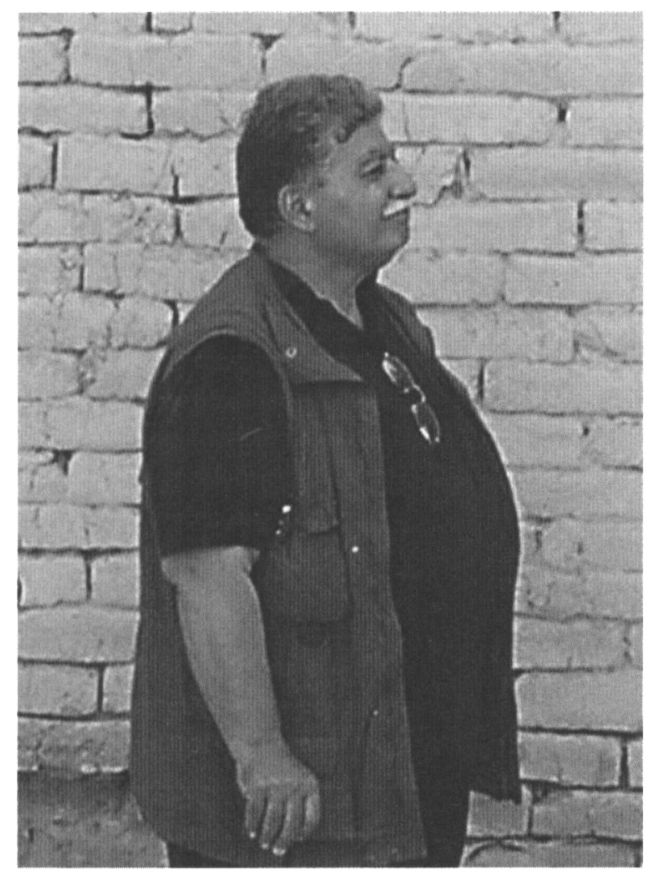

Dr Donny George Youkhanna, ${ }^{1}$ who died on 11 March 2011 at the early age of 60, was instrumental in drawing public attention to the looting of the Iraq Museum in April 2003. Thereafter he played a key role in the recovery of many of the stolen items.

Donny George was born into an Assyrian Christian family on 23 October 1950 on the RAF base at Habbaniyah, where his father worked as an accountant. Later his father moved to Baghdad to work for the British Council. It may well have been this exposure to English at an early age that led to Donny's facility in the language. His fluency was all the more remarkable in that he did not visit Britain or America until 2002, when he came to London for a conference on Nimrud at the British Museum, gave a paper on the craftsmanship of the gold objects from the tombs of the Assyrian queens and contributed to a panel discussion on the Nimrud treasures. ${ }^{2}$ Donny was proud of his Assyrian background, and in the latter stages of his life was a pillar of the Christian community in south Baghdad.

He studied archaeology at Baghdad University, obtaining his B.A. in 1974 and his M.A. in 1986. For his M.A. he wrote a thesis on the architecture of the sixth millennium at Tell es-Sawwan, which was translated into English and published by Nabu Publications in $1997 .{ }^{3}$ His Ph.D., awarded in 1995, was also about Tell es-Sawwan, focusing on the stone statues (called by him the "stone industry"). A manuscript is at present with Dr Lamia al-Ghailani, and will also be published by Nabu Publications in due course.

In 1976 Donny began his long association with the State Board of Antiquities and Heritage (SBAH) when he joined the staff of the Iraq Museum, becoming Director of the Documentation Centre in 1980. In 1986-87 he was field director of the Babylon Restoration Project, a project which had started in 1978 at the personal instigation of Saddam Hussein and culminated in the first

\footnotetext{
1 This is an expanded version of an obituary written by myself that appeared in The Times for 23 March 2011.

${ }^{2}$ See J. E. Curtis et al. (eds.), New Light on Nimrud: Proceedings of the Nimrud Conference $11^{\text {th }}-13^{\text {th }}$ March 2002
}

\footnotetext{
(London 2008) 103-4, 105-18.

${ }^{3}$ Tell es-Sawwan: the Architecture of the Sixth Millennium B.C. (London 1997).
} 
Babylon International Festival in September 1987. This extravaganza lasted for a month and unashamedly portrayed Saddam as the successor of kings Hammurabi and Nebuchadnezzar. Although Donny had private reservations about some aspects of the restoration project, such as the creation of three artificial lakes on the surface of the site and the heaping up of three gigantic mounds, on one of which was built a palace for Saddam, he justified his involvement in it to himself on the grounds that the restoration of buildings such as the Southern Palace of Nebuchadnezzar was worthwhile, as it provided visitors to ancient Babylon with something to see.

It is certainly true that, without any restoration, mud-brick sites such as Babylon can often be disappointing, and many cultural-heritage experts would support some degree of restoration. The main questions are the scale and nature of the restoration, but these decisions were out of the hands of the archaeologists working at Babylon. It is often forgotten that in a totalitarian state, such as Iraq used to be, the whim of the ruler is paramount. In the same vein, it would have been very difficult for anybody in Saddam's Iraq to work in a government department without belonging to the Baath Party, and it was completely unreasonable for a few journalists and others later to criticize Donny for his (low-level) membership of the party.

Other projects during these years with the SBAH included excavations at Nineveh (1988) and in the Bekhma Dam region (1989). The discovery of the tombs of the Assyrian queens at Nimrud in 1989 90 gave Donny the opportunity to use his skills as a photographer. He personally took outstandingly good photographs of the gold jewellery and other treasures found in the tombs. The photographs were later taken by Donny to the USA, and it is to be hoped that they will be published in full in the near future. On their own they constitute an outstanding legacy.

In the difficult years after the first Gulf war in 1991, when Iraq had to contend with sanctions and the looting of museums and archaeological sites, ${ }^{4}$ Donny became the trusted lieutenant of $\mathrm{Dr}$ Muayyad Damerji, the Chairman of the SBAH, and they worked closely together to protect Iraq's archaeological heritage. As part of the policy to deter looters, excavations were organized at a number of sites in southern Iraq where there had been bad looting, particularly in the period 1994 95. Donny himself took charge of the excavations at the large and important Sumerian site of Umm al-Aqarib in eastern Dhi Qar province. Working there in 1999-2000 was so dangerous that he was obliged to carry a gun at all times and was accompanied by armed guards. His excavation revealed remains mainly of the Early Dynastic Period (third millennium BC), including a large administrative building, probably a palace, some graves and a temple. An article on the excavations appeared in the Festschrift for David Oates, written by Donny and Haidar Abdul Wahed. ${ }^{5}$ After the second Gulf war in 2003 there was unfortunately a further outbreak of looting at Umm al-Aqarib.

In 2000 Donny became Director-General of Research and Studies in the SBAH, and was in this position at the time of the second Gulf war. In many lectures delivered in various parts of the world, and in several published accounts, ${ }^{6}$ Donny described the sequence of events leading up to the looting of the museum and its aftermath. As a senior member of staff in the SBAH he was in charge of a team that shared the responsibility for looking after the Iraq Museum on a rota basis. This was felt to be a necessary precaution in view of the fact that a number of provincial museums had been looted during the first Gulf war in 1991, but it was never envisaged that the national museum would be left unprotected after the Americans had occupied Baghdad.

According to the rota Donny was supposed to be in charge of the team protecting the Iraq Museum over the first weekend of April 2003. In fact, he was not able to reach the museum on Saturday 5 April as fighting intensified in Baghdad and many roads were blocked off, but he was able to get there on Sunday 6 April, when he joined a number of other staff. That night and the following night they stayed in the museum. Then on the morning of Tuesday 8 April they were

\footnotetext{
${ }^{4}$ For a brief account by Donny George of damage to Iraqi cultural heritage during and after the first Gulf war see his foreword to M. Polk and A. M. H. Schuster (eds), The Looting of the Iraq Museum, Baghdad: the Lost Legacy of Ancient Mesopotamia (New York 2005) 1-3.

5 "Temple ' $\mathrm{H}$ ' at Umm al Aqarib", in L. Al-Gailani Werr et al. (eds.), Of Pots and Plans: Papers on the Archaeology and History of Mesopotamia and Syria Presented to David
}

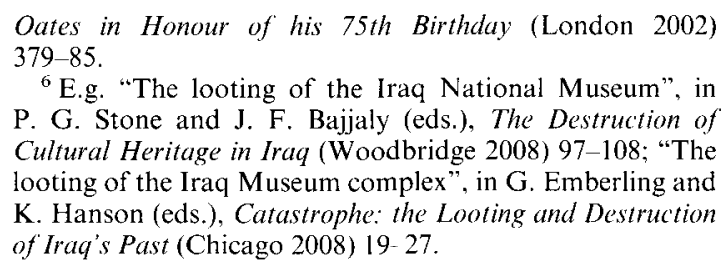

${ }^{6}$ E.g. "The looting of the Iraq National Museum", in P. G. Stone and J. F. Bajjaly (eds.), The Destruction of Cultural Heritage in Iraq (Woodbridge 2008) 97-108; "The looting of the Iraq Museum complex", in G. Emberling and K. Hanson (eds.), Catastrophe: the Looting and Destruction of Iraq's Past (Chicago 2008) 19 27. 
woken at five a.m. by the sound of fierce fighting in the neighbourhood of the museum. At a hastily convened meeting Dr Jaber Khalil, then the Chairman of the State Board of Antiquities and Heritage, gave the remaining staff the option of leaving or staying on at the museum. Donny elected to remain, together with Dr Jaber, an SBAH employee and his son who lived on the premises, and a driver, making a group of five in all. They were intending to stay for as long as possible in the basement of the museum and had collected emergency rations for this purpose.

In the event, however, they were obliged to leave the museum later that morning at about eleven a.m. Dr Jaber had noticed that four or five Iraqi resistance fighters armed with rocket-propelled grenades had jumped into the front garden of the museum and were preparing to do battle with advancing American tanks. There were also American helicopters overhead, and it seemed that the museum would be at the centre of a fierce battle. Dr Jaber therefore ordered everybody to leave. They locked up and moved to the ethnographic museum on the east side of the River Tigris, intending to return later. They tried to come back at about three o'clock in the afternoon but by that time American forces were more or less in control of the whole area, and it was not possible. They were not able to travel around Baghdad again until Sunday 13 April, when Donny and Jaber returned to the Iraq Museum and were met with a scene of devastation. Despite the warnings of possible looting from scholars in America and Britain, as well as from the Iraqis themselves, the museum had been left entirely unprotected by American forces. Looting had broken out on 10 April and continued until 12 April, when journalists arrived to record what was happening, effectively putting an end to the disturbances.

Even now, more than eight years later, there is no precise record of how many objects of the Iraq Museum were taken or damaged, but it is usually reckoned that around 16,000 objects were stolen from the storerooms, including the world-renowned collection of cylinder seals, and about forty iconic objects from the galleries. These had been left behind when the galleries were emptied before the war. At the same time, many exhibition cases were smashed, offices were broken into and ransacked, and there was a trail of destruction throughout the museum. For the next few days, Donny and Jaber held the fort in the museum, keeping potential looters at bay. During this time the site still remained unguarded and it was not until the morning of Wednesday 16 April that American tanks finally arrived to secure the site. This followed a satellite-telephone conversation on the previous day with colleagues in the British Museum, courtesy of Channel 4 News, when Donny had reported that the site was still unguarded. This information was passed on to the Prime Minister's office and presumably from there to Washington.

During these days Donny and Jaber were under siege from reporters desperate for information about this cultural-heritage disaster, and it was then that Donny really came into his own. With his fluent English, easygoing manner and huge charisma he was in much demand from the media, and he did not disappoint them. He gave scores of interviews, using the opportunity not just to publicize what had happened but to highlight the difficulties that were now facing the SBAH. As part of this campaign to bring to the attention of the world the gravity of what had happened, Donny was persuaded to leave Baghdad on 26 April to attend a hastily assembled press conference at the British Museum in London.

On the way to the press conference he and a British Museum colleague were held up by bandits. Donny took this and other violent incidents in his stride, including an attack on his person outside his home that left him with a nasty head wound. Though appearing relatively unruffled, he must actually have been under tremendous pressure at this time and for the next three years. The press conference at the British Museum on the 29 April 2003 was an extraordinary event, with television crews from around the world anxious to listen to Donny. He duly provided a graphic account of what had happened, and in this way he became not only the recognized spokesperson for the Iraq Museum but also, somewhat reluctantly, an international celebrity.

Later in 2003, Donny was appointed Director-General of the Iraq Museum and in 2005 Chairman of the State Board of Antiquities and Heritage. Throughout this time he worked tirelessly to recover stolen artefacts both from within Iraq and from abroad. Some of this work was done in conjunction with US Marine Colonel Matthew Bogdanos, but it was Donny's contacts and knowledge that proved invaluable in persuading local people to return stolen treasures and give information leading to their recovery. 
Early successes included the return of a statue of Shalmaneser III, a bronze relief from Tell al-Ubaid, the Warka vase, the Warka head, and the bronze statue base from Bassetki. At the present time it is estimated that more than half of the forty iconic objects stolen from the galleries have now been recovered, and around eight thousand objects taken from the stores have now been returned, both from within Iraq and from abroad, but not, unfortunately, the collection of cylinder seals. There is no doubt that Donny should be given much of the credit for what has been achieved. He was also active in attempting to protect archaeological sites, many of which were very badly looted in 2003-4. Among the measures he helped to introduce were watchtowers at selected sites and the deployment of special police officers to protect them.

In 2006, in the face of worsening sectarian violence and the persecution of Christians, Donny began to feel that the situation in Iraq was too dangerous for himself and his family. Matters came to a head when his younger son Martin received death threats, and Donny realized the time had come to leave. This became possible through his appointment as a visiting professor in the Department of Asian and Asian-American Studies in the State University of New York at Stony Brook, which was arranged for him by his friend and fellow archaeologist Professor Elizabeth Stone. His classes on Western Asia in general and Mesopotamian civilization in particular were very popular with students. During his years in exile he continued to attend conferences all around the world and to lecture widely about the damage to the Iraqi cultural heritage, and more than anybody else he kept the grave problems confronting Iraqi archaeology and cultural heritage at the forefront of public attention.

Donny died of a heart attack at Toronto airport while on his way to give lectures on two subjects that were close to his heart, the Assyrian gold treasures from Nimrud (at the University of Toronto) and the looting of the Iraq Museum (at the Assyrian-Chaldean-Syriac Student Association in Toronto). He was buried on 19 March in Chicago, where his sister lives and where there is a flourishing Assyrian community. His family has now relocated there. Memorial events for Donny were held on the Stony Brook campus on 8 April and at Stony Brook Manhattan on 14 May. The latter event was attended by friends and colleagues from all over America, and in addition tributes were read out from colleagues in various parts of the world. Among the initiatives prompted by Donny's premature death are a fund to assist his family set up by Elizabeth Stone and Paul Zimansky and administered through the Stony Brook Foundation, and the naming after him of one of the exhibition halls in the Iraq Museum in Baghdad.

Donny had many interests outside archaeology. His involvement with the Christian community has already been referred to, and at one time he was a drummer in a rock band. He was also an accomplished fisherman and a dedicated family man. In academic life, unsurprisingly, many honours came his way. For example he was a corresponding member of the German Archaeological Institute, a lifetime honorary member of the Archeological Institute of America, and a member of the Visiting Committee to the Department of Ancient Near Eastern Art in the Metropolitan Museum of Art in New York.

At the time of his death he was intending to write a book about his experiences from 2003 onwards, with a full and detailed account of his role in the protection of the Iraq Museum, and it is a tragedy that this project was not completed. Nevertheless, Donny George will be remembered for the great work that he did in protecting cultural heritage in Iraq. In addition, he won the respect and friendship of all with whom he came into contact. He bore no grudges and was held in high esteem by people all around the world, both Iraqis and non-Iraqis. Iraqi archaeology has lost one of its ablest and most charismatic advocates.

John E. Curtis 